\title{
Geography and gender studies : the situation in Brazil and Argentina
}

Géographie et études de genre: la situation au Brésil et en Argentine

\section{Susana Veleda da Silva and Diana Lan}

\section{(2) OpenEdition}

12 Journals

\section{Electronic version}

URL: http://journals.openedition.org/belgeo/11227

DOI: $10.4000 /$ belgeo. 11227

ISSN: 2294-9135

Publisher:

National Committee of Geography of Belgium, Société Royale Belge de Géographie

\section{Printed version}

Date of publication: 30 September 2007

Number of pages: $371-382$

ISSN: 1377-2368

\section{Electronic reference}

Susana Veleda da Silva and Diana Lan, « Geography and gender studies : the situation in Brazil and Argentina », Belgeo [Online], 3 | 2007, Online since 11 December 2013, connection on 22 May 2020. URL : http://journals.openedition.org/belgeo/11227 ; DOI : https://doi.org/10.4000/belgeo.11227

This text was automatically generated on 22 May 2020.

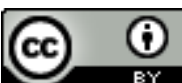

Belgeo est mis à disposition selon les termes de la licence Creative Commons Attribution 4.0 International. 


\title{
Geography and gender studies : the situation in Brazil and Argentina
}

Géographie et études de genre : la situation au Brésil et en Argentine

\author{
Susana Veleda da Silva and Diana Lan
}

\section{Introduction}

The objective of this article is to offer a panoramic survey of geographic research that has engaged with feminist thinking in Latin America over the last twenty years. Across the continent such an orientation is quite rare (Morales, 1997). For this reason, we will concentrate our review on Argentina and Brazil, the countries in which gender research originated within the discipline. While we emphasize research in geography, we note that attention to gender has come quite late within it when compared to other social sciences. In order to contextualize the development of gender research in geography, however, we think it is important first to give an overview of Latin American feminist movements, even though these have been, and in many cases still remain, outside of academia. We will also refer to the development of gender studies in other social sciences.

Over the last several decades Latin American feminisms have developed under conditions that have differed considerably from those experienced by feminists in Europe and the United States. Existing under changing regimes of military dictatorships, the returns to democracy, and the impacts of globalization and neoliberalism, they present a political project committed to social change, human rights and equality, and with an important orientation to concerns of social class. This contrasts with the stronger middle class orientations of feminist activism in the northern countries. Latin American feminists of the 1960s and 1970s, by comparison, were more closely connected with leftist, revolutionary parties and for some, with a strong Marxist tradition (Cangiano \& Dubois, 1993). They had their origins in the working classes and arose in a context of profound radicalization and class struggle. The social crises of the 1960s in the Western world, such as the student movements of 
1968 and the withdrawal of the welfare state, struck a chord in Latin American in countries such as Brazil, Argentina, Mexico, and Colombia among others (Santos, 1996). In some, such as Brazil and Argentina, suffering under political dictatorships gave rise to strikes by workers and student movements. Simultaneously, the expansion of industrialization and growing urbanization saw salaries deteriorating and costs of living escalating (Brusquini, 1994).

3 In Brazil by the 1970s, the women's movement was flourishing ${ }^{1}$. Principally in Sao Paulo, women in poor neighborhoods and peripheral zones joined with the Catholic church to petition the state to provide the basic necessities to sustain life such as child care (Teles, 1993) but also to seek better wages and to struggle for a more just cost of living. These demands revealed not only a change in mentality but also changes in urban space. Though in this period, some women in leftist groups joined in clandestine mobilisation against the dictatorship, it was women of the working class neighbourhoods who appeared in public spaces and constructed "a dynamic of their own" (Soares, 1994, p. 16), transforming their everyday spaces. That is to say, these women went out from the private sphere in order to seek transformation of the public sphere, to make the social sphere visible; in the process, the boundaries of the public and private were blurred and challenged. Further, from the seventies, the growing participation of women in the Brazilian labour force, as pointed out by Brusquini (1994, p. 179) was "one of most marked social transformations in our country". Additionally, the initiation of the United Nations Decade for Women in 1975 saw the growth in Brazil of feminist groups committed to the struggle for equality and for democratization.

4 In academia in the late 1970s, reflecting the economic issues in society, attention focused on relations of production, probably due to the influence of Marxist ideas. In the social sciences, principally in sociology, studies of women and work in urban and rural contexts began to emerge. At the same time, scholars began to introduce new methodologies into research to give visibility to women in society, advancing approaches such as biographies and life histories that showed women as actors and thinkers.

5 By the 1980s, feminist movements had become present in all the main regions of Brazil, dedicated to reorganizing society and rearticulating relations of power. These movements accompanied the political opening and opportunities to influence the state and the new Constitution of 1988. For example, the reservation of a proportion of parliamentary seats for women in Brazil, known as "lobby do baton" together with the Emendas Populares, through intense mobilization won a series of historical conquests in the Constitution (Pinto, 1992, 1994). During this period, feminist movements were very heterogeneous, with forms of action and objectives varying according to women's region, class, and "race". Within academia, studies in demography and sociology, for example by Elsa Berquó $(1980,1982,1986,1989,1990,1991)$ and Carmen Barroso (1984) analyzed the consequences of falling fertility rates in the country and denounced the practice of indiscriminate female sterilization. Such work was multiplied in studies on the subject of reproductive rights.

6 By the 1990s, the economic crisis and unemployment in the country saw a loss of confidence in the efficacy of social mobilization, yet there were also significant changes in the dispersal and institutionalization of feminist movements. Some of these changes can be identified in the rapid growth of nongovernmental organizations (NGOs), in participation in national and international fora, and in the creation of a state apparatus 
responsible for women's affairs. Attention spread to include a range of themes (health, reproductive rights, violence, environment, among others) and the creation of networks demonstrated new social practices. Despite this institutionalization and growth, many problems remain and advances are lacking in social and gender equality. According to the Ministry of Work, women receive only two-thirds of the income level of men and the differential is expanding. Further, the growth of NGOs and in the numbers of professional feminists has channeled activism to specific questions, such as violence against women and environmental crises, and the tendency to institutionalization has caused many of the social movements to lose their spontaneous and non-hierarchical characteristics.

7 Despite these continuing problems, processes of institutionalization in academia have contributed to advancing research on women and gender in the humanities and social sciences, especially in sociology, anthropology and history. Today we also see timid approaches to incorporating these concerns into Brazilian geography. The questions of equality and difference are very important in feminist movements and within academia in theoretical debates and empirical research. Work groups in universities or in the independent sector are addressing questions of gender relations and are important in connecting the academy and social movements by means of memoranda of agreement (convenios) or by offering courses. In this way universities validate and support the activities of networks and provide infrastructure for integrating movements in the wider society with researchers. It is also the case that feminist scholarship has benefited from the funding by organizations such as the Ford Foundation that has supported publication of the Revista de Estudos Feministas since 1992 in Rio de Janeiro and since 1999 in Florianópolis. This publication, issued twice a year, addresses gender themes across disciplines and reveals the richness of gender studies in Brazil. Its objectives are to give visibility to the existing production and report the theoretical and practical politics of feminist movements and women (Veleda da Silva, 2000a).

The processes that can be observed in Argentina are quite parallel to those in Brazil. In the 1970s, the theoretical questions and themes about women grew outside academia and slowly began to be integrated in the disciplines, particularly in psychology, anthropology, sociology and demography. Argentinian feminists were also focused on class struggles within the country. As a result, analyses took women less into account and moved towards concerns of class (Calvera, 1990). In the mid-1970s, the defeat of the workers' movement and imposition of the dictatorship with the coup d'etat (1976) stifled development of the feminist movement. Social polarization was very great and influenced how feminism was seen : the right considered feminists as subversive and enemies, the left by contrast identified them as petit bourgeois (D'Atri, 2004). The defeat of Argentina in Malvinas war in 1982 was taken as a disciplinary act for Argentina (and the rest of Latin America) and the lesson was very clear: we cannot confront hegemonic powers.

9 With the return of democracy, however, at the end of the 1990s, the feminist movement was renewed and with force. Many women returned from exile, joining those who were already organized to reclaim their "disappeared" imprisoned, and tortured relatives; this process was expressed in the public agenda in terms of "democracy" and "human rights". It permitted feminist demands to be taken up by political parties, international organizations, and local activist groups. The decade of the 1990s, beginning with the defeat of Iraq in the Gulf War at the hands of a coalition led by the United States, saw 
increasing global advances of neoliberalism and further opening of the Argentine economy to international monopolies. This involved the privatisation of state enterprises, the flexibilization of labour, the reduction of public funding and rising unemployment. The structural adjustment policies imposed by the World Bank and other international organizations contributed to and augmented poverty within Argentina and other Latin American countries. A consequence of the neoliberal process has been depoliticization of social movements, including the feminist movement. There are, however, indications that neoliberalism might not succeed, and that has prompted the reappearance of new social movements at the beginning of the $21^{\text {st }}$ century, including feminist movements. Thus we see a return of feminist mobilizations and their presence in demonstrations against globalization, as in the critical moments of December, 2001 in Argentina when feminists appeared with their distinctive posters at the demonstrations.

\section{Gender Developments in Geography in Latin America : the cases of Brazil and Argentina}

10 The question that has directed our research on the discipline is "Does the geography of gender exist in Latin America?". We have tried to identify all the work produced over the last twenty years. This is a difficult but attractive task, one that has been frustrating because gender is very little studied in Latin American geography with the only significant production in Brazil and Argentina.

\section{Gender Studies in Brazilian Geography}

Although gender research is only incipient in Brazil in comparison with the extent of the work in Europe and the United States, we are impressed that it can be identified in postgraduate courses for almost twenty years. We will report on the work that has been completed in public universities since the 1980s, but emphasize that, although we have made an exhaustive search, it has not been possible to access all records or to identify what teaching has taken place.

Brazilian geographers began to treat the theme of gender quite timidly at the end of the 1980s. The pioneer was Rosa Ester Rossini (University of Sao Paulo) (Rossini,1988) who wrote her doctoral thesis on women's work in the sugar industry of Sao Paulo. Between 1987 and 2000 she also directed four master's theses at the University on gender (Andrighetti, 1987; Watron, 1992; Francisco, 1993; Garcia, 2002) and one doctoral thesis (Vicenti, 2002). The most common theme in this research was the study of women's work in Sao Paulo ; both rural and urban settings have been included. These studies have accomplished the goal of giving visibility to women but have not examined gender relations. An additional doctoral thesis on women's participation in the labour market of Sao Paulo was also completed in this period at the Federal University of Rio de Janeiro (Viana, 1989). Since 2000, Rossini has written two articles on the new technologies and the incorporation of women and men in society (Rossini, 2002, 2004).

In the 1990s, although the theme of work was not abandoned (Almeida, 1996) researchers began to branch out with new studies in urban geography, health, and population. Notable is the doctoral thesis by Sonia Calio (1991) which introduced feminist theoretical perspectives on gender relations into urban geography. Bison 
(1995) studied migration from rural to metropolitan areas and Veleda da Silva's (1999a, 1999b) study, which examined the options of surgical sterilization, was a modest effort to introduce theoretical perspectives and was innovative in focusing on men as well as women. It is notable, that with two exceptions, all the research reported above was produced at the University of Sao Paulo and has focused almost entirely on that region. Since 2000 , by comparison with the previous two decades, the range of topics, the locations of interest and array of the institutions involved has expanded and conceptual issues have been addressed (Veleda da Silva, 2000a, 2002b, 2002c). New topics have included religion, health, the family in relation to work, and informal sector work. Peripheral regions of the northeast and south of the country have also been studied (Almeida, 1996 ; Malzone, 2001; Garcia, 2001 ; Schefler, 2002 ; Carvalhal, 2003 ; Veleda da Silva, 2000b, 2001, 2002a ; Paegle, 2004). These projects were completed under the direction of both men and women geographers and in several universities, continuing at the University of Sao Paulo but including also the Federal University of Bahia, the Paulista State University Julia Mesquita Filho/Presidente Prudente ; and the Federal University of Parana, as well as the dissertation completed by Veleda da Silva at the Autonomous University of Barcelona (Veleda da Silva, 2004). Two of these studies (Almeida, 1996; Carvahal, 2000) emerged from a work group on gender relations created at Presidente Prudente, São Paulo.

In addition to the research for doctoral and master's theses, gender studies have begun to emerge to a small extent in symposia and publications. The journal, Boletim de Geografia Teorética in 1992 published empirical studies on women and work in geography and other social sciences. Despite the title of the journal, however, these studies did not consistently exhibit theoretical perspectives. Then in 1996, El Boletim Gaúcho de Geografia published two articles (Rosing, 1996; Shaaf, 1996) on the role of women workers in the construction of the city and on the situation of rural women; two years later Veleda da Silva (1998) published an article introducing theoretical perspectives on gender. An article by Melo (2001) was also published in the journal Revista Electrônica Pegada. New interest in cultural geography has recently opened some space for discussions of gender, notably at the $4^{\text {th }}$ National Symposium in "Space and Culture" an initiative of the Centre of Study on Space and Culture in the Department of Geography of the State University of Rio de Janeiro at which the woman professor, Joceli Maria da Silva ${ }^{2}$, was invited to speak on space and gender.

Though these individual theses, publications, and the symposium are significant, we must point out that initiatives on the part of institutions and geographical associations, which are necessary if the field is to develop, have been lacking. This gap is notable at a time when government policies have become sensitive to gender issues and there is a special Secretary for Women, as well as a strong commitment to support actions related to gender and the promotion of social equality. Thus it appears to us paradoxical that our discipline ignores these themes and, moreover, that our associations of geographers do not consider investigations of gender relevant to include in postgraduate courses. We argue that it is essential to include gender as a category of analysis across all areas of geography, rather than it being only set up as a separate focus. Nevertheless, we also think that if gender studies are to advance in geography in Latin America, and particularly in Brazil, it is additionally necessary to treat them as a separate theme in order to gain visibility. Brazilian geography, as has been the case in English-speaking countries, needs to pay attention to social movements and to use the 
category of gender in social analysis to understand the ways in which societies and spaces are shaped, rather than describing gender as an outcome of different geographic spaces. It must incorporate the theoretical contributions of feminism and study empirically how space is modified by social movements and by gender inequalities. In this way gender studies will present a challenge for those who try to understand the new ways of conceptualizing space in geography.

\section{Gender and Geography in Argentina}

17 A focus on gender in geography, if very recent in Argentina, constitutes a perspective not widely found in Latin America. This situation is shared by other social sciences, although in general they have been ahead of geography in introducing gender. The ideas emerged in the 1980s and were defined in the 1990s. We attribute this late introduction partly to the persistence of the preoccupation with quantitative spatial analysis and its focus on developing universal theories as well as the discipline's tendency to ignore themes related to social change. Alternative viewpoints came into Argentinian geography via studies in perception, radical geography and cultural humanistic work. They recognized society as not neutral but as heterogeneous and began to interpret the production and consumption of space as shaped more by sociocultural than economic factors. Gender studies were also early in introducing the postmodern position of not accepting knowledge as fixed, universal, neutral and objective. They argued that categories of analysis need to be deconstructed, to take account of the significance of the place in constructions of gender, and to recognize that different scales of analysis and connections between scales (global-local) should be emphasized. Through such recognitions, a new paradigm was introduced in which gender is understood as socially, culturally and contextually constructed, significant in the production and consumption of space, in differential uses of space, in relations between women and men and in divisions of labour.

the last fifteen years, regional geography conferences have been held in several parts of Argentina at which presentations on gender have been made, for example, at the $1^{\text {st }}$ and $2^{\text {nd }}$ Symposia on Geography in La Plata in 1994 and 2000 (Colombara, 1995 ; Tadeo, 1995, 2000 ; Lucero et al., 2000 ; Lan et al., 2000a ; Tadeo \& Fidele, 2000) and at Lomas de Zamora in 1999 (Colombara \& Pelizzari, 1999a). The latter could be considered the first occasion on which a specific meeting was dedicated to exploration of expressions of gender within the local context; it was organized by Monica Colombara who then held the position of Full Member for Latin America of the International Geographical Union Commission on Gender and Geography.

At the national level, gender studies could be said to have been introduced in 1997 at the $6^{\text {th }}$ Congress of Latin American Geographers in Buenos Aires when papers were dedicated to the theme by Monica Colombara (1997) and Nidia Tadeo (1997) whom we consider the pioneers of gender studies in geography in Argentina. Also at this Congress, one of the invited plenary addresses was delivered by Maria Dolors GarciaRamon of the Autonomous University of Barcelona and an informal meeting was held by geographers interested in gender. The First International Humboldt Congress in Buenos Aires in 1999 represented the first full session dedicated to scholarly papers on gender. Several presentations were given (Colombara \& Pelizarri, 1999b ; Garcia, 1999 ; Tadeo \& Fidele, 1999). Leticia Garcia's paper at this meeting, on gender and work, was 
important in connecting local expressions to global processes; we consider her to be another of the pioneers, along with the group of geographers at the National University of La Plata. Papers were also presented at the $8^{\text {th }}$ Congress in Santiago de Chile (Lucero et al., 2001 ; Garcia et al., 2001 ; Lan et al., 2001). There was not another session bringing together the work on gender until the $10^{\text {th }}$ Meeting in San Pablo in 2005 when a round table was dedicated to "Women and Socio-Spatial Dynamics" coordinated by Rosa Ester Rossini representing Brazil and which included participants representing Brazil and Argentina (Colombara, 2005).

In addition to oral presentations, publications exist in scientific journals such as the work by Kloster (1998) on migration and the work of Andean women and in a special edition of Huellas dedicated to geography and gender. It includes papers by geographers at the University of La Pampa on women in space-time (Martinez, 1999), research on women's voting in La Pampa (Medus, 1999) and working class women's combining of paid and domestic work (Garcia, 1999a). Lan and colleagues have also published an array of papers $(2000 \mathrm{~b}, 2003,2004)$ and presented their research at several meetings in geographic or interdisciplinary settings (Lan, 2001; Lan \& Di Nucci, 2000, 2001, 2005 ; Lan et al., 2000a, 2000b, 2005) focusing especially on urban themes and daily uses of space and time. Reviewing the location of the authors of the presentations and publications and the topics addressed, two points stand out. First, work on gender has been carried out in an array of institutions and by a growing number of geographers. Second, the topics addressed include themes that reflect a number of the issues that have been of concern to feminists outside the academy, including aspects of women's situation in the workforce, relations between home, family and work, domestic violence, connections between the global and the local, voting behaviour and thinking and actions about gender and the natural environment (Colombara, 2006). Additionally, articles have examined conceptual approaches to gender analysis and to the construction and uses of space-time.

21 Scientific work in Argentina is supported by governmental institutions such as CONICET (the National Commission for Scientific and Technical Research), and national universities are free and public. It is in these settings that geographic work with a focus on gender is carried out. We had intended to make an inventory of lines of research in geography that have institutional status (that is, that have been evaluated and accredited, for example, by the national system of incentives for faculty), but the only one that we can identify is the group on Gender and Space (Lan, 2000) established at the National Central University of the Province of Buenos Aires. Since 2006 this group has formed part of the Research Program on Territory and Society set up under the National Program of Incentives within the Center for Geographic Research.

We have also been concerned to assess how gender research is received within geography programs. The case of the National Central University represents both some of the accomplishments and some of the difficulties encountered. Within the geography program in the Faculty of Human Sciences a program entitled Social Geography has had a unit dedicated to geography of gender since 2000 which has continued without difficulties. This contrasts with the situation in the Program on Environmental Management. In that context, in a unit entitled "Population and Environment" for $4^{\text {th }}$ semester students, material on gender was offered by the same faculty who taught in Social Geography. In the Environmental Program these faculty were removed from their functions following the presentation of a series of non-academic arguments by 
students, among which was the claim that the professors were too ideological and included too much on gender themes. This action prompted various defenses on the part of the faculty involved. The debate concluded with a resolution of the Academic Council asking for an apology from the students who had previously criticized the ideological position of the professors. The case represents an example of the challenges that can arise when attempts are made to introduce gender as a category of analysis into the curriculum in which such a development is recent and little known. Such cases merit wider publicity and discussions of internal institutional politics.

Although we have not made a study of the unrecognized discrimination to which women in academic environments in Argentina are subjected, we do see this as contributing to the obstacles that teaching and research on gender and social relations face in Argentina. Further, we see as a challenge that many women in the academy do not have a consciousness of gender issues, further influencing the lack of analysis of social relations. Finally, we consider that studies of women and gender in Argentina are further handicapped because they have yet to develop an adequate theoretical approach to permit them to rise to appropriate academic and scientific levels.

\section{Some Concluding Thoughts}

By way of synthesis, we can say that gender is an active perspective in theoretical, epistemological and methodological aspects of our science, and is contributing to its development, although it is very incipient in Latin America. The research in Brazil has taken up concerns that relate to those of the feminist movement, especially issues of women's place in the workforce and the problems that arise as they attempt to combine home and work and to survive under conditions of economic stress. To this research geographers bring an analysis of space and feminist theoretical understandings of the social and cultural construction of gender. Additionally, geographers have addressed concerns of reproductive rights, domestic violence, and women's engagement with environmental affairs and activism.

The influences of the political and economic contexts have been clear in affecting when, where, and what kinds of work have been done. Notably, and reflecting where feminist movements were initially most active in Brazil, the earliest research was concentrated at the University of Sao Paulo, focused on issues of women and work, and addressed places in that state, though it has subsequently spread to other regions. The developments have generally come later in Argentina, and reveal a wide range of topics and dispersed locations. The impact of political repression, economic crises, later democratization and institutional development can be seen in the timing and nature of the scholarly production and its acceptance. Overall, in reviewing the development of gender studies in geography such as presentations at Congresses and in symposia, we consider that it has begun to be recognized slowly but sustainably in Brazil and Argentina. The challenge for geography of gender at the beginning of the $21^{\text {st }}$ century is to gain a firmer footing in the discipline and in the many interdisciplinary university centres devoted to interdisciplinary work in Latin America. 


\section{BIBLIOGRAPHY}

ANDRIGHETTI Y. (1987), Mulher e trabalho. A operária têxtil paulistana, Master's Dissertation in Geography, University of São Paulo.

ALMEIDA R. (1996), A mulher no mercado de trabalho : um estudo sobre a força de trabalho feminina no setor secundário em Presidente Prudente/SP, Master's Dissertation in Geography, State University of São Paulo/UNESP.

BARROSO C. (1984), “Esterilização feminina : liberdade e opressão”, Revista de Saúde Pública, 18 (2), pp. 170-180.

BERQUÓ E. (1980), Algumas indicações sobre a recente queda da fecundidade no Brasil, Paper presented at the Meetings of the Working Group on Processes Population Reproduction, Teresópolis.

BERQUÓ E. (1982), “Os corpos silenciados”, Novos Estudos, Centro Brasileiro de Estudos Populacionais/CEBRAP, 1 (3), pp. 46-49.

BERQUÓ E. (1986), “Sobre o declínio da fecundidade e a anticoncepção em São Paulo”, Textos Monográfici do Núcleo de Estudos Populacionais/NEPO, 6, p. 52.

BERQUÓ E. (1989), “A família no século XXI : um enfoque demográfico”, Revista Brasileira de Estudos da População, 6, 2, pp. 20-36.

BERQUÓ E. (1990), “Uma nova onda para atropelar os direitos reprodutivos”, Revista Brasileira de Ciências Sociais, 7, 1, pp. 86-94.

BERQUÓ E. (1994), “Esterilização e raça em São Paulo", Revista Brasileira de Estudos da População, 11, $1,19-26$.

BISON W. (1995), Volta por cima : mulheres migrantes entre o Vale de Jequitinhonha e São Paulo, Master's Dissertation in Geography, University of Sao Paulo.

BRUSQUINI C. (1994), "O trabalho da mulher no Brasil : tendências recentes", Anais do III Encontro Nacional de Estudos do Trabalho, São Paulo, Associação Brasileira de estudos do Trabalho/ABET, pp. 15-40.

CALIÓ S. (1991), Relações de gênero na cidade : Uma contribuição do pensamento feminista a Geografia Humana, Doctoral Thesis in Geography, University of São Paulo.

CALVERA L. (1990), Mujeres y Feminismo en Argentina, Buenos Aires, Grupo Editor Latinamericano.

CANGIANO M.C. \& DUBOIS L. (1993), “De mujer a género : Teoría, interpretación y práctica feminista en las ciencias sociales”, in CANGIANO M.C. \& DUBOIS L. (eds.), De Mujer a Género : Teoría, Interpretación y Práctica Feminista en las Ciencias Sociales, Buenos Aires, Centro Editor de Latinoamericano, pp. 7-16.

CARVALHAL T. (2003), A questão de gênero nos sindicatos de Presidente Prudente/SP, Master's Dissertation in Geography, State University of São Paulo.

COLOMBARA M. (1992), “Espacio y mujer. Una contribución a la geografía del género”, Boletín de Estudios Geográficos, 25, 89, pp. 25-33.

COLOMBARA M. (1995), “Cual es el rol jugado por las mujeres en el ámbito geográfico universitario argentino ? Su análisis desde la perspectiva de género", Actas Primeras Jornadas Platenses de Geografia, La Plata, National University of La Plata, pp. 202-209. 
COLOMBARA M. (1997), La introducción de la categoría de género en los documentos internacionales. El caso del informe de Desarrollo Humano de $1995,6^{\text {th }}$ Encuentro de Geográfos de América Latina, Buenos Aires, CD.

COLOMBARA M. (2005), La perspectiva de género en proyectos y programas de desarrollo, $10^{\text {th }}$ Encuentro de Geográfos de América Latina, San Pablo, Brazil.

COLOMBARA M. (2006), “Género, ambiente y desarrollo. Desde caminos paralelos a la transversalidad”, Revista Geográfica Venezolana, 47, 2, pp. 157-186.

COLOMBARA M. \& PELIZZARI V. (1999), Violencia doméstica. Cuestión privada o pública. Su estado en América Latina, Primeras Jornadas Latinoamericanas de Género y Geografia, Lomas de Zamora.

D'ATRI A. (2004), “Entre la insolencia de las luchas populares y la mesura de la institucionalización", Feminismo Latinamericano. Revista Lucha de Clases 2, http ://www.pts.org.ar/ luchaClase2genero.htm, p. 6.

FRANCISCO M. (1993), Trabalho familiar na agricultura do município de Rio Claro/SP : a mulher e a criança na pequena produção, Master's Dissertation in Geography, University of São Paulo.

GARCIA D. (2002), o feminino no bairro : a experiência pela prevenção do câncer de mama e de colo de útero na zona leste do município de São Paulo - 1994-1997, Master's Dissertation in Geography, University of Sao Paulo.

GARCIA A. (2001), As mulheres da cidade D'Oxum : relações de gênero, raça e classe e organização espacial do movimento de bairo em Salvador, Master's Dissertation in Geography, Federal University of Bahia/UFBA.

GARCIA L. (1999a), "Mujeres populares : entre el trabajo productivo y la organización doméstica", Huellas (Special Issue, Geografía del Género), 4, pp. 49-90.

GARCIA L. (1999b), Género y trabajo. Procesos globales y su incidencia local, $1^{\text {st }}$ Encuentro Internacional Humboldt, Buenos Aires, CD, p. 12.

GARCIA L., DILLON B., POMBO D., CALDERON A., GEBEL I., \& AMBROSIN A. (2001), Turismo rural y género. Un estudio de caso, $8^{\text {th }}$ Encuentro de Geógrafos de América Latina, Santiago, Chile, CD, p. 9.

KLOSTER E. (1998), “Migración y Trabajo de las mujeres en San Martín de los Andes”, Meridiano, 6, pp. 71-77.

LAN D (2000), “Implicancias territoriales del género como construcción social”, Reflexiones Geograficas, 9, pp. 126-131.

LAN D. (2001), Doble jornada laboral e invisibilidad del trabajo de las mujeres. Notas a partir de un caso, $5^{\text {th }}$ Congreso Nacional de Estudios del Trabajo, Asociación Argentina de Especialistas en Estudios del Trabajo, Faculty of Economic Sciences, University of Buenos Aires.

LAN D. \& DI NUCCI J. (2000), Movilidad y accesibilidad urbana, según género en la ciudad de Tandil. Argentina, $21^{\text {st }}$ National Congress and $6^{\text {th }}$ International Geography Congress, Temuco, Chile, CD, p. 12.

LAN D., GOMEZ S., MIKKELSEN C. \& DI NUCCI J. (2000a), Las responsabilidades familiares desde la perspectiva de género : el caso de la ciudad de Tandil, $2^{\text {nd }}$ Jornadas Platenses de Geografía, Department of Geography, Faculty of Humanities and Educational Sciences, National University of La Plata, La Plata, CD, p. 13.

LAN D., GOMEZ S., DI NUCCI J \& MIKKELSEN C. (2000b), "Procesos globales e implicancias locales en el uso del tiempo y del espacio, según genero, en Tandil”, Estudios Socioterritoliales, 1, 1, pp. 117-132. 
LAN D. \& VELAZQUEZ G., (2003), "Social Structure, Gender and Territory in Tandil, Argentina”, in ANUP S. (ed.), Population environment and the challenge of development, Section IV : Socio-economic perspectives, New Delhi, Akansha Publishing house, pp. 304-326.

LAN D, \& GOMEZ S. (2004), "La ciudad desde un enfoque de género", in VIDALIA M. \& HEREDIA N. (eds.), Pensamiento Feminista II : Aportes para un nuevo andamiaje social, Córdoba, CEN Ediciones, pp. 275- 288.

LAN D., GOMEZ S. \& DI NUCCI J. (2005), "La construcción del espacio cotidiano a través de los desplazamientos urbanos diarios, según género”, in BERTONCELLO R., CASTRO H. \& ZUSMAN P. (eds.), Taller Internacional : Desplazamientos, Contactos, Lugares.La experiencia de la movilidad y la construcción de otras geografías, Institute of Geography, Faculty of Philosophy and Letters, University of Buenos Aires, CD, p. 8.

LUCERO P., RIVIERE I., DESIDERIO M. \& MASCARETTI S. (2000), Lugar cotidiano y género. Un acercamiento al estudio de los movimientos territoriales de varones y mujeres según la condición social en Mar del Plata, $2^{\text {nd }}$ Jornadas Platenses de Geografía, Departamento de Geography, Faculty of Humanities and Educational Sciences, National University of La Plata, CD, p. 13.

LUCERO P., RIVIERE I., DESIDERIO M., \& MASCARETTI S. (2001), Trabajo, educación y territorio desde la perspectiva de género, en una ciudad intermedia en los noventa, $8^{\text {th }}$ Encuentro de Geógrafos de América Latina, Santiago, Chile, CD, p. 9.

MALZONE R. (2001), A participação da mulher, o crescimento das religiões/crenças e a produção do espaço em São José do Rio Preto, Master's Dissertation in Geography, University of Sao Paulo.

MARTINEZ I. (1999), “El protagonismo femenino en el espacio-tiempo territorial”, Huellas (Special Issue, Geografía del Género), 4, pp. 19-30.

MEDUS B. (1999), "El voto femenino en la Pampa : Tres localidades en un estudio de caso", Huellas (Special Issue, Geografía del Género), 4, pp. 31-48.

MELO E. (2001) "Gênero e jornada de trabalho em assentamentos rurais", Revista Electrônica Pegada, 2, p. 2.

MORALES S. (1997), "La geografía del género en América Latina : Una aproximación a través del análisis bibliométrico”, Boletín de Estudios Geogràfico, 94, pp. 193-221.

PAEGLE L. (2004), Espaços do cotidiano feminino no bairro Mercês/Curitiba : um estudo de geografia e gênero, Master's Dissertation in Geography, Federal University of Paraná/UFPR.

PINTO C. (1992), Movimentos sociais : espaços privilegiados da mulher enquanto, São Paulo, Rosa dos Tempos.

PINTO C. (1994), "Participação (representação ?) política da mulher no Brasil : limites e perspectivas”, in SAFFIOTI H. \& MUNOZ-VARGAS M. (comp.), Mulher Brasileira é assim, Rio de Janeiro, Rosa dos Tempos, pp. 195-230.

ROSING T. (1996), "O papel da mulher profissional na construção da cidadania”, Boletim Gaúcho de Geografia, 21, pp. 77-81.

ROSSINI R. (1988), Geografia e gênero : a mulher na lavoura canavieira paulista, Tese Livre Docência, University of São Paulo.

ROSSINI R. (2002), “Nas atividades econômicas a modernidade tecnológica exclui homens e mulheres. Incorpora mais a mulher na cidade e menos no campo", Espaço e Tempo GeoUSP, 12, pp. 47-56. 
ROSSINI R. (2004), "Superando a discriminação : mulher e trabalho na modernidade tecnológica no Brasil”, in SAMARA E. (comp.), Populações : (Com)vivêcia e (In)tolerância, São Paulo, Humanitas, 4, pp. 245-257.

SANTOS B. (1996), Pela mão de Alice - o social e o político na pós-modernidad, São Paulo, Cortez.

SCHEFLER M. (2002), Mulheres guardiãs da terra e da vida : um estudo de caso sobre o papel multifuncional da mulher na organização familiar, Master's Dissertation in Geography, Federal University of Bahia/UFBA.

SHAAF A. (1996), “A mulher rural”, Boletim Gaúcho de Geografia, 21, pp. 83-93.

SILVA J. (2003), "Um ensaio sobre as potencialidades do uso do conceito de gênero na análise geográfica”, Revista de História Regional, 8, 1, pp. 31- 45.

SOARES V. (1994), "Movimento Feminista. Paradigmas e desafios", Revista de Estudos Feministas (Special Issue), pp. 11- 24.

TADEO N. (1995), “Género y trabajo. La contribución del trabajo feminino en la explotación agrícola familiar”, Actas Primeras Jornadas Platenses de Géografia, Department of Geography, National University of La Plata, pp. 210-235.

TADEO N. (1997), Los desplazamientos cotidianos de las mujeres. Hacia una redefinición de las relaciones de género, $6^{\text {th }}$ Encuentro de Geografos de América Latina, Facultad de Filosofía y Letras, Universidad de Buenos Aires, CD, p. 8.

TADEO N. (2000), “Mujeres y movimientos de acción ambiental”, Estudios Socioterritoriales, 1 (1), pp. 149-158.

TADEO N. \& FEDELE M. (1999), Gestión ambiental y género. Una perspectiva geográfica, $1^{\text {st }}$ Encuentro Internacional Humboldt, Buenos Aires, CD, p. 12.

TADEO N. \& FEDELE M. (2000), Contribuciones del feminismo a la teoría geográfica. Relaciones entre género y ambiente, $2^{\text {nd }}$ Jornadas Platenses de Geografía, Departamento de Geography, Faculty of Humanities and Educational Sciences, National University of La Plata, CD, p. 13.

TELES M. (1993), Breve história do feminismo no Brasil, São Paulo, Brasiliense.

VELEDA DA SILVA S. (1998), “Geografia e gênero/Geografia feminista - o que é isto ?”, Boletim Gaúcho de Geografia, 23, pp. 105-111.

VELEDA DA SILVA S. (1999a), Não quero mais filhos... a opção pela esterilização cirúrgica no município do Rio Grande, Master's Dissertation in Sociology, Porto Alegre, Federal University of Rio Grande do Sul/UFRGS.

VELEDA DA SILVA S. (1999b), “Algunas considerações sobre o opção pela esterização cirúrgica no município do Rio Grande”, in ALVES F. (comp.) Por uma história multidisciplinar do Rio Grande, Rio Grande, Federal University of Rio Grande/ FURG, pp. 67-71.

VELEDA DA SILVA S. (2000a), "Os estudos de gênero no Brasil : algumas considerações”, Biblos 3W : Revista Bibliográfica de Geografía y Ciencias Sociales, 5, 262.

VELEDA DA SILVA S. (2000b), "Inovações nas Políticas Populacionais : o Planajemento Familiar no Brasil”, Scripta Nova. Revista Electrónica de Geografía y Ciencias Sociales, 69, 38.

VELEDA DA SILVA S. (2001), "Desplazamientos y relación con los lugares : um estudio cualitativo”, Scripta Nova. Revista Electrónica de Geografía y Ciencias Sociales, 94, 102.

VELEDA DA SILVA S. (2002a), "Lãs mujeres camelôs. Uma relación entre lugar, trabajo y hogar", Scripta Nova. Revista Electrónica de Geografía y Ciencias Sociales, 119, 30. 
VELEDA DA SILVA S. (2002b), "Intentando aclarar conceptos : igualdad/diferencia y relaciones de gênero”, in PAUNERO AMIGO F.X. et al. (eds.), Mercosur : desarrollo sostenible y territorio, Girona, Universitat de Girona, pp. 283-286.

VELEDA DA SILVA S. (2002c), "Geografia del comercio : viejas formas nuevos enfoques", Treballs de la Societat Catalana de Geografia, 53-54, pp. 175-189.

VELEDA DA SILVA S. (2004), Trabajo informal, género y cultura : el comercio callejero e informal em el sur de Brasil, Doctoral Thesis in Geography, Autonomous University of Barcelona.

VIANA M. (1989), Recessão e participação feminina no mercado de trabalho no estado de São Paulo, Master's Dissertation in Geography, University of Sao Paulo.

VICENTI M. (1998), Inserção da força de trabalho feminino : as bóias frias na agricultura do sudoeste paulista, Doctoral Thesis in Geography, University of Sao Paulo.

WATRON C. (1992), Mulher e saúde. Um estudo de mulheres atendidas no centro de saúde, Master's Dissertation in Geography, University of Sao Paulo.

\section{NOTES}

1. Although at the end of the $19^{\text {th }}$ century there had been the movement by women to gain the vote and workers' strikes for better salaries and conditions (Teles, 1993), it was in the 1970s that the movements assumed new social practices.

2. She is a professor of geography at the State University of Ponta Grossa/UEPG in Paraná (in southern Brazil). Her work demonstrates that geographic studies on gender are spreading to other regions (Silva, 2003).

\section{ABSTRACTS}

Feminist geography in Latin America has developed primarily in Brazil and Argentina. We first situate research in relation to feminist movements in society which were shaped by working class activism and affected by local and global political and economic currents. We then examine the implications of recent institutionalized feminisms for academia. In both countries, we identify the inclusion of gender perspectives in geography as modest and relatively recent reflecting the discipline's orientations to positivist and Marxist perspectives. Such feminist work as exists is more empirical than theoretical. In Brazil, early work centered in Sao Paulo and emphasized aspects of women's productive work with some research on health issues. In Argentina it has been more dispersed institutionally and topically, with attention to urban spacetime themes, environment, migration, and political participation. Special journal issues have been published and meeting sessions organized, but the field remains to become institutionalized in curricula and professional organizations. Yet we conclude the field is making slow but sustained progress.

En Amérique Latine, la géographie féministe s'est d'abord développée au Brésil et en Argentine. Nous avons d'abord situé la recherche en rapport avec les mouvements féministes dans la société, mouvements qui ont été façonnés par l'activisme de la classe ouvrière et affectés par les 
courants politiques et économiques locaux et généraux. Nous avons ensuite examiné les implications des féminismes institutionnalisés récemment pour l'académie/l'université. Dans ces deux pays nous avons identifié l'inclusion des perspectives de genre en géographie comme étant modeste et relativement récente, reflet des orientations de la discipline vers des perspectives positivistes et marxistes. Les travaux féministes actuels sont plus empiriques que théoriques. Au Brésil, les travaux plus anciens ont été concentrés à Sao Paulo et ont souligné les aspects du travail productif des femmes avec des recherches sur les questions de santé. En Argentine, les travaux ont été davantage dispersés institutionnellement et thématiquement, avec une attention particulière aux questions urbaines d'espace-temps, à l'environnement, aux migrations et à la participation politique. Des numéros spéciaux de revues ont été édités et des sessions de conférences organisées mais il faut encore que ce domaine soit institutionnalisé en programmes d'études et en organisations professionnelles. En conclusion, il est à noter que le domaine fait des progrès lents mais soutenus.

INDEX

Mots-clés: feminist geography, social movements, research directions

\section{AUTHORS}

\section{SUSANA VELEDA DA SILVA}

Departamento de Geociências, Universidade Federal do Rio Grande, Rio Grande (Brasil), sucasilva@yahoo.com.br

\section{DIANA LAN}

Centro de Investigaciones Geográficas, Universidad Nacional del Centro de la Provincia de Buenos Aires, Buenos Aires (Argentina), dlan@fch.unicen.edu.ar 